\title{
On the Issue of the Effectiveness of Legal Regulation Based on Psychological Aspects
}

\section{Sobre el tema de la efectividad de la regulación legal basada en aspectos psicológicos}

\author{
Valery P. Belyaev*
}

Southwest State University, Kursk, Russia.

ORCID: https://orcid.org/0000-0003-2666-9047

\section{Galina S. Belyaeva}

Belgorod State University, Belgorod, Russia.

ORCID: https://orcid.org/0000-0003-2494-6928

\section{Vladislav Yu. Turanin}

Belgorod State University, Belgorod, Russia. ORCID: https://orcid.org/0000-0001-7766-8648

\section{Tamila M. Nincieva}

Chechen State University, Grozny, Russia. ORCID: https://orcid.org/0000-0002-8874-1553

\section{Natalia S. Avdeeva}

Belgorod State University, Belgorod, Russia. ORCID: https://orcid.org/0000-0002-1740-7451

Received 12-12-19 Revised 01-25-20 Accepted 04-14-20 On line 04-21-20

*Correspondence

Email: belvp46@mail.ru
Cite as:

Belyae, V. P., Belyaeva, G. S., Turanin, V. Yu., Nincieva, T. M., \& Avdeeva, N. S. (2020). On the Issue of the Effectiveness of Legal Regulation Based on Psychological Aspects. Propósitos y Representaciones, 8(2), e509. Doi: http://dx.doi.org/10.20511/pyr2020.v8n2.509 


\section{Summary}

This article is devoted to the analysis of problems regarding the main approaches to understanding the effectiveness of legal regulation and the search for its criteria. It is known that this issue serves as the basis for ongoing social development, ensuring optimal law-making and law enforcement activities of state bodies, achieving the goals of the procedural and legal regulation, consisting in ensuring, within certain stages of the legal and reasonable consideration and resolution of legal cases, the adoption of appropriate procedural decisions in the interests of subjects of law. The effectiveness of legal regulation is determined by a kind of evaluation category, the essence of which is to determine the level of functionality and effectiveness of this process in its dynamics. As criteria for the effectiveness of procedural and legal regulation are called effectiveness, achievement of the goal, procedural savings and others.

Keywords: Law; Legal Regulation; Procedural Legal Regulation; Efficiency; Optimality Expediency; Effectiveness of Legal Regulation; Criteria of Effectiveness.

\section{Resumen}

Este artículo está dedicado al análisis de problemas relacionados con los principales enfoques para comprender la efectividad de la regulación legal y la búsqueda de sus criterios. Se sabe que este tema sirve como base para el desarrollo social continuo, asegurando actividades óptimas de elaboración de la ley y de aplicación de la ley de los organismos estatales, logrando los objetivos de la regulación procesal y legal, que consiste en garantizar, dentro de ciertas etapas de lo legal y razonable consideración y resolución de casos legales, la adopción de decisiones procesales apropiadas en interés de los sujetos de derecho. La efectividad de la regulación legal está determinada por un tipo de categoría de evaluación, cuya esencia es determinar el nivel de funcionalidad y efectividad de este proceso en su dinámica. Como criterios para la efectividad de la regulación procesal y legal se llaman efectividad, logro de la meta, ahorro procesal y otros.

Palabras clave: Ley; regulación legal; Regulación legal procesal; eficiencia; Óptima conveniencia; Efectividad de la regulación legal; Criterios de efectividad.

\section{Introduction}

The modernizing social processes taking place in the Russian Federation inevitably require the transformation of the Russian legal system, the degree of development of which does not fully correspond to the dynamics and needs of modern society: social security and safety of citizens, their sociocultural and intellectual progress. The objective needs of the social development of our state require the creation of a single concept of modernization of procedural and legal regulation and its main components in order to implement the programmatic provisions of the Constitution of the Russian Federation, the issues of building of the civil society, legal and social state.

In this aspect, it seems relevant to address to the issue of the effectiveness of procedural and legal regulation, identifying and fixing its criteria and conditions, which serves as the basis for ongoing social development, ensuring optimal law-making and law enforcement activities of state bodies, achieving the goals of legal regulation, which consist in ensuring certain stages of legal and reasonable consideration and resolution of legal cases, the adoption of appropriate ruling procedure in the interests of subjects of law.

The main problems requiring resolution in this area are the definition of the general legal concept of "efficiency" and the establishment of criteria (indicators) for this as applied to the procedural and legal component of this process. At present, various descriptive constructions are 
being put forward of what should be and what should include procedural and legal regulation and what are the criteria for its effectiveness, requiring generalization at the level of the conceptual approach.

Thus, the relevance of a scientific problem is due to the following factors: firstly, sociopolitical (changes in the socio-economic and political spheres, an increase in crisis phenomena, various social and humanitarian risks, and, consequently, the need to transform the procedural and legal regulation in accordance with the needs of social development); Secondly, by scientific and theoretical (insufficient scientific development of the categories of "procedural and legal regulation", "mechanism of procedural and legal regulation", "legal tools", "legal process", the absence of their holistic consistent scientific concept and their unsystematic use at the same time, as legislator and law enforcement); Thirdly, practical (the need to optimize legal regulation in appropriate legal forms, legal and effective legal means, including the processualization of the main types of state activity).

\section{Methodo}

The methodological basis of the study is based on the application of various general scientific methods and methods of scientific knowledge (analysis, synthesis, deduction, induction, systemstructural, formal-logical approaches), as well as particular scientific methods - formal-legal and interpretative.

\section{Results and Discussion}

Anticipating the consideration of the concept and criteria of the effectiveness of procedural and legal regulation, we would like to note the fact that at present the concept of the effectiveness of law has spread throughout the social sphere and has created the basis for its use in different meanings, in connection with which the issue of the exact definition becomes relevant to this concept with a distinction of efficiency with such related categories as optimality and expediency.

First, it is interesting to study the concept of social efficiency. "Efficiency is the (often measurable) ability to avoid wasting materials, energy, efforts, money, and time in doing something or in producing a desired result. In a more general sense, it is the ability to do things well, successfully, and without waste" (Oxford English Dictionary, 2005).

It should be mentioned that at a time when the discussion of the effectiveness of law was just beginning, this concept was equated with optimality, validity, expediency, and correctness. Moreover, it was believed that the study of effectiveness should always be complemented by the study of optimality. From our point of view, it is impossible to put an equal sign between the concepts of efficiency and optimality, since a priori the rule of law can (and should!) be optimal; in order for it to become effective certain conditions must be created.

Regarding the distinction between the concepts of "efficiency" and "expediency" it should be noted that we believe that the general scientific definition of "expediency" is closely related to the categories of "goal" and "rationality," that is, it is an evaluation category in which the human factor plays the leading role. The concept of "expediency", in comparison with efficiency, is characterized by less stability. This also applies to the legal sphere, where effectiveness is determined by circumstances, tasks in a specific situation and is as close as possible to the average person. However, only a subject with special knowledge is entitled to evaluate a legal phenomenon, an action as effective (Lebedev, 1963).

Now we turn to a direct examination of the effectiveness in relation to the subject of this study. At the same time, we believe that it will be productive to study both efficiency in general and the effectiveness of law (norms of law, law), the effectiveness of the mechanism of legal regulation, etc. 
On the effectiveness of legal regulation in general S.S. Alekseev notes: "The most important aspect of the mechanism of legal regulation is to ensure the effectiveness of the impact of law on public relations. The effectiveness of legal regulation is the feasibility and effectiveness of legal measures, legal norms" (Alekseev, 1966). And in this case, the importance of efficiency comes first.

In general terms, in our opinion, efficiency should be understood as the relationship between the result actually achieved and the goal that was supposed to be realized. Confirmation of this judgment is the dictionary definition of effectiveness (from the adjective effective): "leading to results, effective" (The American Heritage Dictionary, 2019).

As regards the understanding of effectiveness in relation to law and legal norms, at one time a number of scientists proposed to understand the effectiveness of law as the correlation of the actual result of the operation of legal norms with the social goals for which these norms were adopted (Belyae, Belyaeva, Turanin, Nincieva, \& Avdeeva, 1980; Tihomirov, 2009; Lejst, 2002).

From the point of view of E. Hirsch, the social effectiveness of law is "the ratio of the frequency of acts of lawful behavior to acts of behavior that deviates from the requirements of legal norms" (Hirsh, 1996). In this case, the effectiveness of law is considered from the perspective of lawful behavior.

In the above definitions of effectiveness, in spite of some differences, a similar view of the category under study is demonstrated, namely: highlighting the social orientation as a criterion of effectiveness.

M.Ju. Osipov, when studying the effectiveness of the rule of law, distinguishes such a criterion as "the level of their realizability by the subjects of those social relations, the regulation of which they were aimed at. The higher the level of feasibility is, the higher is the formal effectiveness of the rule of law. The lower the level is, the lower is the level of effectiveness. Such an approach will make it possible to more clearly determine whether this rule of law is effective or not from the point of view of the formal approach" (Osipov, 2009). One can agree with this position of this author, but only on the condition that, along with the level of feasibility, it is possible to highlight other criteria for the effectiveness of law.

And in conclusion of the undertaken review of the opinions of scientists on the problem, we also refer to the concept of efficiency, proposed by the representative of general theoretical science V.M. Raw. In his opinion, "efficiency is the ratio between the goals of a legal phenomenon and the result of the action of this legal phenomenon" (Syryh, 2004). This approach to understanding effectiveness in law (according to V.M.Syrykh - in the legal phenomenon) is shared by us, since it is acceptable for characterizing procedural and legal regulation.

It is well known that any rule of law operates in a real spatio-temporal environment in the circle of persons who are subjects of public relations. External factors determine the parameters of the rule of law, and thus have an indirect effect on the effectiveness of procedural and legal regulation, while being the conditions for increasing its effectiveness. According to N.V. Tkachev, the effectiveness of any legal norm depends on conditions such as: "social value, the perfection of legislation, legality, the proper level of implementation of legal norms, the degree of awareness of addressees about their contents, the level of legal awareness and legal culture of subjects" (Tkachjova, 2004) (including procedural rules, we clarify); the conditions named by this author fully apply to the effectiveness of procedural and legal regulation.

Along with the foregoing, among the conditions for the effectiveness of the law (legal norm, legal impact), scientists include: the perfection of legislation and law enforcement; the level of legal culture of a society and an individual; state of law; the creation of a specific, clear, understandable and accessible to every citizen system of incentives and restrictions in law, 
individual and differentiated approaches to their implementation, systemic unity, complexity in the use of these legal tools and others (Zhukova, Kislitsyna, Mamin, Abbasov, Aghajanian, 2018; Belyaeva, Bogdanov, Nikolaev, Ostapyuk, Samsonov, 2018; Makogo, Markhgeym, Minasyan, Novikova, Yarychev, 2019).

As a result of the foregoing, it can be determined that the effectiveness of procedural and legal regulation is a kind of assessment category, the essence of which is to determine the level of functionality and effectiveness of this process in its dynamics. That is, the mechanism of procedural and legal regulation becomes effective only when its goal (result) is achieved: legal cases are successfully, legally and reasonably considered and resolved. Efficiency criteria should include (indeed, being peculiar parameters) and effectiveness, and achievement of goals, stability, etc.

The undertaken analysis of the given points of view on the issue of determining criteria for the effectiveness of legal regulation, legal norms, etc. allows to formulate own opinion on the criteria of procedural and legal regulation. It looks as follows: as criteria for the effectiveness of procedural and legal regulation, it is possible to recognize the following:

a) efficiency;

b) the achievement of the goal;

c) procedural savings, understood in this case, as achieving a goal with minimal costs;

d) the ratio (security) of the interests of the individual, society and the state;

d) the stability of the result; (environment).

f) mobility and adequacy of the action (functioning) of a particular situation

Of course, the proposed criteria for the effectiveness of legal regulation are not comprehensive; moreover, they are somewhat arbitrary and require their further "improvement". However, we believe that the proposed system sufficiently provides an opportunity for a general theoretical understanding of the problem of the effectiveness of procedural and legal regulation.

At the same time, we note that, along with the foregoing, the level of legal awareness and legal culture in society has a certain influence on the effectiveness of procedural and legal regulation. Legal culture and legal awareness are inextricably linked with each other and determine the vector of development of law in general.

Legal culture is largely the resulting category, an indicator of the level and characteristics of the legal development of society, a mirror of its legal consciousness, since the implementation of the provisions of the rule of law depends to a large extent on whether the addressees agreed with the content, whether they recognized the necessity and fairness of legal requirements, whether they came to the conclusion about the importance of their steady implementation.

Legal awareness is a tool (means) of translating the requirements of legal norms to their practical implementation. Of course, legal consciousness has a significant impact on the functioning of the mechanism of legal regulation, linking together the content of legal regulation with the real interests of legal entities. A low level of legal consciousness reduces the effective application of the rule of law, and, therefore, does not contribute to the effectiveness of both the mechanism of legal regulation in general and the mechanism of procedural and legal regulation in particular.

In our opinion, when assessing the effectiveness of legal regulation, it is also necessary to take into account the professional level (training) of subjects (especially leading) of legal relations as part of the legal regulation mechanism. The presence of procedural legislation, as well as the means, methods and conditions for the implementation of the tasks set, will only then 
"work" for efficiency when their processually correct, legal and justified, implementation (implementation) is achieved at the appropriate professional level.

Thus, the effectiveness of procedural and legal regulation is, first of all, its effectiveness, the ability to solve the necessary tasks and ensure the achievement of its goals. The criteria for the effectiveness of the mechanism of procedural and legal regulation, mentioned above, set the parameters of efficiency, being at the same time an evaluation category (Turanin, Pozharova, Kurilenko, Rumyantsev, \& Krikun, 2019; Turanin, Tonkov, Kuprieva, Pozharova, \& Turanina, 2019).

\section{Conclusions}

As a result of the theoretical and legal analysis of approaches to understanding the effectiveness of procedural and legal regulation and its criteria, the following conclusions can be drawn.

Firstly, the effectiveness of legal regulation is a kind of evaluation category, the essence of which is to determine the level of functionality and effectiveness of this process in its dynamics.

Secondly, the mechanism of procedural and legal regulation becomes effective only when its goal (result) is achieved: legal cases are successfully, legally and reasonably considered and resolved.

Thirdly, it is possible to recognize as criteria for the effectiveness of procedural and legal regulation: a) effectiveness, b) achievement of the set goal, c) procedural savings, understood in this case, as achieving the goal with minimal costs, d) correlation (ensuring) the interests of the individual, society and the state, e) stability of the achieved result, e) mobility and adequacy of the action (functioning) of a particular situation (environment).

\section{References}

Alekseev, S. S. (1966). Mehanizm pravovogo regulirovanija v socialisticheskom gosudarstve. Moskva, 32 (in Russian).

Belyaeva, G., Bogdanov, S., Nikolaev, A., Ostapyuk, V., Samsonov, V. (2018). Administrative legal regulation principles of restrictions on human rights and freedoms of citizens. Herald NAMSCA, 3, 1141-1144.

Glazyrin, V. V., Kudrjavcev, V. N., Nikitinskij, V. I., \& Samoshhenko, I. S. (1980). Jeffektivnost' pravovyh norm. Moskva, 22, p. 280 (in Russian).

Hirsh, E. E. (1996). Das Recht im sozialen. Westberlin, S. p. 157.

Lebedev, M. P. (1963). Ob jeffektivnosti vozdejstvija socialisticheskogo prava na obshhestvennye otnoshenija. Sovetskoe gosudarstvo i pravo, 1(31) (in Russian).

Lejst, O. Je. (2002). Sushhnost' prava. M., S. p. 93 (in Russian).

Makogon, B., Markhgeym, M., Minasyan, A., Novikova, A., Yarychev, N. (2019). Logical classification of legal procedural restrictions. Revista Inclusiones, 6(2), 395-401.

Osipov, M. Ju. (2009). Ponjatie jeffektivnosti pravovyh processov i problemy ee opredelenija. Leningradskij juridicheskij zhurnal, 3, 32-33 (in Russian).

Oxford English Dictionary (3rd ed.). (2005). Oxford University Press. September.

Syryh, V. M. (2004). Logicheskie osnovanija obshhej teorii gosudarstva i prava. p. 265 (in Russian).

The American Heritage Dictionary. (2019). Houghton Mifflin Harcourt. Date Views 21.11.2019. https://www.ldoceonline.com/dictionary/efficiency.

Tihomirov, Ju. A. (2009). Jeffektivnost' zakona: ot celi k rezul'tatu. Zhurnal rossijskogo prava, 4, 3-4 (in Russian).

Tkachjova, N. V. (2004). Mery presechenija, ne svjazannye s zakljucheniem pod strazhu, v ugolovnom processe Rossii. Cheljabinsk, p. 92. (in Russian). 
Turanin, V. Y., Pozharova, L. A., Kurilenko, N. N., Rumyantsev, M. B., \& Krikun, V. G. (2019). Systematization of legal terms in regional lawmaking. Dilemas Contemporáneos: Educación, Política y Valore, 6(Special), 34-45.

Turanin, V. Y., Tonkov, E. E., Kuprieva, I. A., Pozharova, L. A., \& Turanina, N. A. (2019). Legal terminology phenomenon in the context of modern legal system evolution. Humanities \& Social Sciences, 7(4), 1291-1295.

Zhukova, N., Kislitsyna, I., Mamin, S., Abbasov, N., \& Aghajanian, A. (2018). Problems of procedural rights abuse. Herald NAMSCA, 3, 1149-1152. 